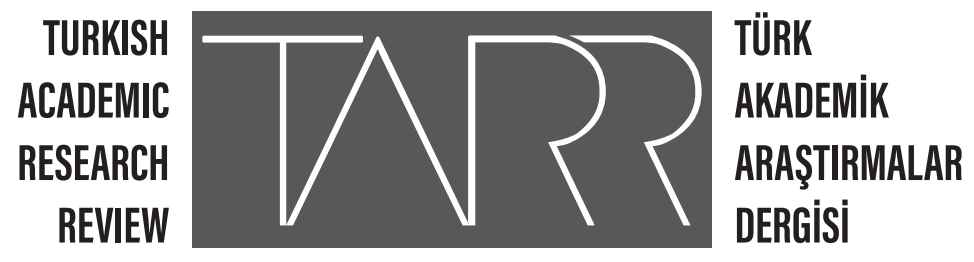

Ergenlerde Dindarlık, Narsizm Ve Özgüven

The Relation Between Religious Devotion, Narcissism And Self-Esteem

In Adolescent: The Case Of Korkutelı

\title{
Orhan GÜRSU
}

Doç. Dr., Akdeniz Üniversitesi, Din Psikolojisi ABD.

Assoc. Prof. Dr., Akdeniz University, Theology Faculty, Phschology of Religion,

E-posta: orhangursu1@gmail.com,

Orcid: 0000-0002-7478-371X

\section{Fatmana Semiha ÖNCE ÖZOKUDAN}

\author{
Akdeniz Üniversitesi, Din Psikolojisi Yüksek Lisans Öğrencisi, \\ E-Posta: semiha_once@hotmail.com \\ Orcid.org: 0000-0001-8883-3194 \\ Makale Bilgisi | Article Information \\ Makale Türü-Article Type | Araştırma Makalesi / Research Article \\ Geliş Tarihi-Date Received | 19 Kasım / November 2019 \\ Kabul Tarihi-Date Accepted | 25 Aralik/December 2019 \\ Yayın Tarihi-Date Published | 31 Aralık/December 2019 \\ Yayın Sezonu | Ekim-Kasım - Aralık \\ Pub Date Season | October - November - December
}

Atıf/Cite as: Gürsu, Orhan-Önce Özokudan, Fatmana Semiha, Ergenlerde Dindarlı, Narsizm Ve Özgüven/The Relation Between Religıous Devotıon, Narcissism And Self-Esteem In Adolescent: The Case Of Korkutelı. tarr: Turkish Academic Research Review, 4 (4),439-454. doi: 10.30622/ tarr.648729

Intihal /Plagiarism: Bu makale, en az iki hakem tarafından incelenmiş ve intihal içermediği teyit edilmiştir. / This article has been reviewed by at least two referees and confirmed to include no plagiarism. https://dergipark.org.tr/tr/pub/tarr

Copyright (C) Published by Mehmet ŞAHİN Since 2016- Akdeniz University, Faculty of Theology, Antalya, 07058 Turkey. All rights reserved. 


\title{
Ergenlerde Dindarlık, Narsizm ve Özgüven ${ }^{1 *}$
}

\author{
Orhan GÜRSU² \\ Fatmana Semiha ÖNCE ÖZOKUDAN ${ }^{3}$
}

Öz

$\mathrm{Bu}$ araştırma, lise öğrencilerinde dindarlık, narsizm ve özgüven arasındaki ilişkiyi incelemeyi amaçlamıştır. Çalışmada, Antalya ilinin Korkuteli ilçesinde altı farklı lisede öğrenim gören 606 öğrenciyle anket çalışması yürütülmüştür. Öğrencilere, Demografik Bilgi Formu, Dini Tutum ve Davranış Ölçme Envanteri, Narsizm Ölçeği ve Özgüven Ölçeği verilerek değişkenlere yönelik veriler toplanmıştır. Araştırma soru ve hipotezlerinin yanıtlanması amacıyla istatistiksel analiz yöntemleri uygulanan çalışmada elde edilen bulgulara göre, dindarlık ile narsizm ve özgüven arasında negatif yönlü ve anlamlı ilişki bulunmuştur. Regresyon analizi bulgularına göre dindarlık, narsizm ve özgüveni negatif ve anlamlı düzeyde yordamaktadır. Ayrıca, demografik değişkenler bakımından dindarlık, narsizm ve özgüven alt boyutları ve toplam skorları karşılaştırıldığında, cinsiyet, sınıf, yaş, lise türü, ebeveyn eğitim durumu, ailede dini yatkınlık ve yaşanılan yer değişkenlerine göre anlamlı farklılıklar saptanmıştır. Araştırmada elde edilen bulgular doğrultusunda, lise öğrencilerinin dindarlıkları ile ilişkili olabilecek kişilik ve psikolojik faktörlerin incelemesi yapılmıştır.

Anahtar Kelimeler: Ergenlik, Dindarlık, Narsizm, Özgüven

\section{The Relation Between Religious Devotion, Narcissism and Self-Esteem in Adolescent: The Case of Korkuteli}

\author{
Abstract \\ This study aimed to investigate the relationship between religiousness, narcissism and self-con- \\ fidence among high school students. In this study, 606 students from six different high schools \\ in the town of Korkuteli which is located in the province of Antalya were surveyed. Demograp- \\ 1 * Bu makale "Ergenlerde Dindarlık, Narsizm ve Özgüven İlişkisi: Korkuteli Örneği” adlı yüksek lisans tezi esas \\ alınarak hazırlanmıştır. \\ 2 Doç. Dr., Akdeniz Üniversitesi, Din Psikolojisi ABD. E-posta: orhangursu1@gmail.com, Orcid: 0000-0002-7478- \\ $371 \mathrm{X}$ \\ 3 Akdeniz Üniversitesi, Din Psikolojisi Yüksek Lisans Öğrencisi, E-Posta: semiha_once@hotmail.com
}


hic Information Form, Religious Attitude and Behavior Measurement Inventory, Narcissism Scale and Self-Confidence Scale were given to the students. In the study, statistical analysis methods were applied in order to answer the research questions and hypotheses. In addition, a negative and significant relationship was found between student's religiousness and self-confidence and narcissism. According to the regression analysis, religiousness predicted narcissism and self-confidence negatively and significantly. In addition, when religiousness, narcissism and self-confidence sub-dimensions and total scores were compared in terms of demographic variables, significant differences were found according to variables such as gender, age, class, high school type, parental education level, religiosity of family and place of residence. In line with the findings of the study, personality and psychological factors related to religiousness and behaviors of high school students were examined.

Keywords: Adolescent, Narcissism, Religiousness, Self-Esteem

\section{Giriș}

Ergenlik dönemi, ergen için hızlı gelişim ve olgunlaşmanın yaşandığı, karakterinin şekillenmesinde önemli rol oynayan evrelerden birisi olmakla birlikte hem genç hem de ailesi için birçok değişikliği kapsamaktadır. Fiziksel, psikolojik, bilişsel, ahlaki, dini ve sosyal açılardan çok yönlü bir gelişim ve değişim dönemi geçiren genç için bu süreç elbette çeşitli zorluklar, kargaşa ve karmaşalar barındırmaktadır (Şahin ve Özçelik, 2016: 42; Cihangir Çankaya ve Meydan; 2018: 207; Gül ve Güneş, 2009: 79). Bu dönemde yaşanan önemli sorunlardan birisi de Narsizm ve özgüven problemidir.

"Narsizm" terimi Yunan mitolojisinde Narkissos karakterinin anlatıldığı bir efsaneye dayanmaktadır. Narkissos, Echo isimli peri kızının aşkına karşılık vermemesinden dolayı göldeki yansımasına âşık olmakla lanetlenmiştir. Yansımasına hasret çekip dokunamadığı için eriyip güzel bir çiçeğe dönüşmüştür. Anlamlı bir trajediyi barındıran bu efsane, saplantılı ve aşırı öz-sevgi sona erdiğinde güzelliğin geleceğini anlatmaktadır (Behary, 2018: 31).

Narsizm kelimesi etimolojik olarak incelendiğinde ise kelimenin kökünün Yunanca' da kunt$l_{\text {luk }}^{4}$ ya da duyarsızlık anlamına gelen narke kelimesi ile ilişkili olduğu görülmektedir. Narsizm kavramı, aşırı öz-sevgi, kendini olduğundan büyük görme ve benmerkezcilik anlamlarına gelmektedir (Budak, 2009: 506). Kibirlilik, gösterişçilik, kendini beğenmişlik, azamet ve benmerkezcilik ise narsizme işaret etmek üzere yaygın olarak kullanılan diğer kavramlardır (Twenge ve Campbell, 2015: 43).

Bireyin doğuştan getirdiği biyolojik özellik ve içinde yaşadığ1 sosyal çevre, onun kimlik ve kişiliğini oluşturan önemli etmenlerdir. Hâlihazırda ise, teknoloji ve internetin etkisiyle sanal bir çevreye de sahip olan gençler araştırma verilerine göre stres, kaygı ve depresyon gibi psikolojik sorunlara daha kolay yakalanabilmektedirler. Araştırmalar bir kişilik bozukluğu olarak ifade edilen narsizmin salgın haline geldiğini; yakın zamana kadar psikolojik sağlık ile pozitif yönlü

4 Ağırlık, dayanıklılık, sertlik, kalınlık, sağlamlık manalarına gelmektedir. 
ilişkili olarak değerlendirilen özsaygı ve özgüven kavramlarının narsizm ile birbirine karıştırıldığını ve bu kişilik özelliklerini geliştirmek için sarf edilen çabaların narsizmi yükselttiğini ortaya koymaktadır (Gürsu, 2016: 33).

Bulaşıcı hastalık derecesinde yaygın olan narsizm olgusunu inceleyen Twenge, ABD'deki ergenlerin son 50 yılda yaşadıkları değişimleri 2006 yılında yayımlanan Ben Nesli isimli kitabıyla ortaya koyarken 2009 yılında ise Campbell ile birlikte yayımladıkları Asrın Vebası: Narsisizm Illet $i$ isimli kitapta yetişkin ve ergenlerdeki narsizmi ele almaktadır. Uluslararası alanda yapılan çalışmalar olduğu gibi son yıllarda ülkemizde de hem yayılma hızı hem de gençleri etkilemesi göz önüne alınarak narsizm ile ilgili çalışmalar yapılmaktadır. Aynı zamanda dinin bireyin gelişimindeki etkisi ve patolojik rahatsızlıkların tedavisindeki iyileştirici yönü nedeniyle dindarlık ve narsizm olguları birlikte ele alınmaktadır. Diğer yandan yakın zamanlara kadar olumlu ve sağlıklı bir kişilik özelliği olarak kabul edilen yüksek özgüvenin narsizmle karıştırıldığı ve özgüveni yükseltmek için gösterilen çabaların narsizmi arttırdığı son zamanlarda yapılan çalışmalarda ifade edilmektedir.

Öz kavramı bir kişinin kendisine ait algılarının toplamını ifade etmek için kullanılmaktadır. Öz kavramı, çok boyutlu olup özgüven ve özsaygı kavramlarını da kapsamaktadır. Özsaygı (self-esteem), özgüven (self-confidence), kendini algilama (self-perception), benlik (self-concept), benlik gücü (ego-strength), özbenimseyiş (self-acceptance) kavramların ilgili literatürde genellikle birbirlerinin yerine geçtiği bilhassa özgüven ve özsaygının eş anlamlı olarak kullanıldı̆̆ı, üstelik çoğu zaman özgüven yerine özsaygının kullanıldı̆̆ 1 ifade edilmektedir. Ayrıca, The Gale Encyclopedia of Psychology adlı psikoloji sözlüğünde özsaygının özgüveni içerdiği belirtilmektedir (Schunk, 2000; Gürsu, 2016: 33).

Özgüven; bireyin tutum ve davranışlarını belirleyen, kendisine yönelik duygu, düşünce ve değerlendirmeleri içeren bir kavramdır (Lauster, 2000). Yakın zamanlara kadar yüksek özgüven olumlu, sağlıklı bir kişilik özelliği olarak değerlendirilmiştir. Ne var ki çalışmalar yüksek özgüven, özsaygı ile narsizmin genellikle birbirine karıştırıldığını, özsaygıyı yükseltmek için kullanılan bütün tekniklerin gerçekte narsizmi artırdığını ortaya koymaktadır. Çalışmalara göre Narsistik Kişilik Envanterinde yüksek puan alan bireylerin özgüven ve özsayg1 puanları da yüksek çıkmaktadır (Twenge ve Campbell, 2010: 50-53). Bu alanda gerçekleştirdiği çok sayıda çalışmasıyla bilinen Baumeister tarafından gerçekleştirilen deneysel çalışmada sanıldığının tersine saldırganlığın asıl kaynağının hak edilmemiş yüksek özgüven olduğu bulgusuna ulaşmıştır. Araştırmaya göre gençlerde özgüven geliştirmenin faydasına yönelik düşüncelerin mit olmaktan öteye geçmediği dile getirilmektedir (Baumeister, 2001: 96-101).

Tarih boyunca sayısı insan ve toplumun hayatında önemli bir yere sahip olan dinin modern zamanla birlikte insan hayatındaki etkisinin ciddi manada azalması sebebiyle dünyanın ergenler için belirsizliklerle dolu kaygan bir zemin haline dönüştüğü vurgulanmaktadır (Giddens, 2004: 100-110). Yine son yıllarda yapılan araştırmalarda din ve patolojik rahatsızlıklar arasında negatif yönlü bir ilişkinin olduğu ve dinin psikolojik rahatsızlıkları iyileştirici etkisinin olduğu ifade edilmektedir. 
Tüm bu veriler dikkate alınarak kişisel gelişim kitapları ve seminerleriyle genç nesillere ve ebeveynlere empoze edilen yüksek özgüven ve özsaygının narsizmi arttırdığını ortaya koymak, patolojik seviyelere ulaşan bu kişilik özellikleri ile bireylerin dindarlık seviyeleri arasında nasıl bir ilişki olduğunu tespit etmek ve bu noktada dinin önemine bir pencere açmak maksadıyla bu çalışmada, ergenlerde dindarlık, narsizm ve özgüven arasındaki ilişki ele alınmakta ve regresyon analizi yapılarak dindarlığın özgüven ve narsizm kavramına etkisi incelenmektedir.

\section{Yöntem}

\section{1. Ölçme Araçları}

\subsubsection{Dini Tutum ve Davranıș Ölçme Envanteri}

Çalışmada Milli Eğitim Bakanlı̆̆g’nın okul rehberlik servislerinde kullanılmasını onayladı̆̆ 36 maddeden oluşan "Dini Tutum ve Davranış Ölçme Envanteri” kullanılmıştır. Ölçeğin özgün formunda uygulandığ gibi toplam skor üzerinden değerlendirme yapılmıştır. Bu çalışma için ölçeğin iç tutarlılık katsayısı .78 olarak tespit edilmiştir.

\subsubsection{Narsizm Ölçeği}

Narsizm ölçeği, kronolojik olarak Raskin ve Hall (1979), Emmons (1984), Raskin ve Terry (1988) tarafından geliştirilen ölçeklerden yararlanılarak Gürsu ve Apaydın (2016: 554-555) tarafindan geliştirilmiştir. 21 madde ve 4 boyuttan (otorite, üstünlük, kendine hayranlık, hak iddia etme) oluşan ölçekte beşli likert tipi (5=Tam katılıyorum...1=Hiç katılmıorum) derecelendirme kullanılmıştır. Gürsu ve Apaydın (2016: 555) tarafından yapılan çalışmanın analiz sonuçlarına dayanarak bazı maddeler ölçekten çıkarılarak madde sayısı 16'ya düşürülmüştür. Araştırmamızda ise ölçek 21 maddelik hali ile kullanılmış, örneklem söz konusu çalışmadan farklı olduğu için açıklayıcı faktör analizi yinelenmiş ve ölçeğin faktör yapısının uyarlama çalışmasıyla tutarlılığ̣ ele alınmıştır. Narsizm ölçeğinin faktör yapısı incelendiğinde dört faktörlü yapının bu çalışmada da sağlandığı görülmektedir. KMO değerleri incelendiğinde .92 olarak bulunmuş ve örneklem yeterliliği iyi düzeyde saptanmıştır. Faktörlerin varyansı açıklayıcılığı incelendiğinde, birinci faktör varyansı \%34,84 oranında açıklamaktadır. İkinci faktör varyans1 \%8,68 oranında açıklamaktadır. Üçüncü faktör, varyansı \%6,90 düzeyinde açıklamaktadır. Dördüncü faktör ise varyansı \%5,0 oranında açıklamaktadır. Dört faktörün toplamı ise varyansı \%55,43 oranında açıklamaktadır. Aynı zamanda bu araştırma için ölçeğin iç tutarlılık katsayısı 0,82 olarak saptanmıştır.

\subsection{4. Özgüven Ölçeği}

2007 yılında Akın tarafından geliştirilen orijinal ölçekten faydalanılarak Gürsu ve Apaydın tarafindan (2016: 555) tarafından geliştirilmiştir. 18 madde ve dört boyuttan (öz-yeterlik, dış özgüven, iç özgüven, girişimcilik) oluşan ölçekte beşli likert tipi (5=Tam kat1lıyorum...1=Hiç 
katılmıyorum) derecelendirme kullanılmıştır. Gürsu ve Apaydın (2016:555) tarafından yapılan çalışmanın analiz sonuçlarına dayanarak bazı maddeler ölçekten çıkarılarak madde sayısı 16'ya düşürülmüştür. Çalışmamızda ise ölçek 18 madde olarak kullanılmış, söz konusu çalışma ile olan örneklem farklılı̆̆ından dolayı açıklayıcı faktör analizi yinelenmiş ve ölçeğin faktör yap1sının uyarlama çalışmasıyla tutarlılığ1 ele alınmıştır. Özgüven ölçeği için KMO değeri 0,860 olarak bulunmuştur. Elde edilen sonucun, örneklem sayısının özgüven ölçeğinin faktör analizini yapmak için yeterli oranda olduğu görülmektedir. Ayrıca, faktörler incelendiğinde, ölçeğin dört faktörlü yapısı olduğu görülmektedir. Ölçeğin ilk faktörü varyansı \%26,01 oranında açıklamaktadır. İkinci faktör ile varyans \%9,79 oranında açıklanmaktadır. Üçüncü faktörlerin varyansı \%6,85 oranında açıkladığı bulunmuştur. Dördüncü faktörün varyansı \%6,04 oranında açıkladığ1 görülmüştür. Dört faktörün toplamda varyansı \%48,69 oranında aç1kladığı bulunmuştur. Ayrıca bu çalışma için ölçeğin iç tutarlılık katsayısı 0,90 olarak tespit edilmiştir ki bu veri ölçeğin doğrulayıcı faktör analizlerinin iyi uyum değerleri verdiğini göstermektedir.

\subsection{Veri Toplama İșlemi}

Araştırma için gerekli görülen demografik değişken sorularından oluşan kişisel bilgi formu,

Dini Tutum ve Davranı̧̧ Ölçme Envanteri, Narsizm ve Özgüven ölçeklerinden oluşan anket formu hazırlanmıştır. Anket 2017-2018 eğitim-öğretim y1lında Antalya ilinin Korkuteli ilçesinde bulunan K1z Anadolu İmam Hatip Lisesi \%15,3 (s=93), Şehit Yasin Naci Ağaroğlu İmam Hatip Lisesi \%14,7 (s=89), Hacı Ethem-Şerife Kavukçu Anadolu Lisesi \%17,0 (s=103), Mesude-Erol Memioğlu Mesleki ve Teknik Anadolu Lisesi \% 16,8 (s=102), Fatma-Mehmet Cadil Fen Lisesi \% 15,7 (s=95), Lokman Hekim Mesleki ve Teknik Anadolu Lisesi \% 19,8 (s=120) kurumlarında uygulanmıştır. Araştırma için Milli Eğitim Müdürlüğü ile görüşülmüş, okul idareleri ve ders öğretmenlerinden izin alınarak katılımcılara anketi doldurmaları için gerekli süre tanınmıştır. Çalışma hakkında bilgilendirme yapılmış, isim istenmediği bizzat vurgulanarak araştırmanın sıhhatli sonuçlanması için katılımcıların çekinmeden kendilerine en yakın olan cevapları vermeleri istenmiştir.

\subsubsection{Verilerin Analizi}

Verilerin analizinde SPSS 24.0 programları kullanılmıştır. Çalışmada, lise öğrencilerinin dini tutum ve davranışlar, narsizm ve özgüven arasındaki ilişkiyi ve demografik değişkenler bakımından farklılaşma düzeyleri incelenmiştir. Dini tutum ve davranışlar, narsizm ve özgüven değişkenlerinin normal dağılım gösterip göstermediğine ilişkin çarpıklık ve eğrilik değerleri verilmiştir. Normal dağılım göstermediği saptanan değişkenlerle, aralarındaki ilişkinin incelenmesi amacıyla "Spearman Korelasyonu” yapılmıştır. İlişkili olduğu tespit edilen değişkenlerin açıklayıcı ilişkisini incelemek için "Doğrusal Regresyon Analizi” uygulanmıştır. Demografik değişkenler ve dini tutum ve davranış, narsizm ve özgüven puanlarının farklılaşma düzeylerinin incelenmesi için, karşılaştırılan bağımsız değişkenlerin homojen dağılım göstermemesi sebebiyle parametrik olmayan Mann Whitney U testi ve Kruskal Wallis H Testi uygulanmıştır. Analizlerde anlamlılık değeri 0,05 düzeyinde \%95 aralığında incelenmiştir. 


\subsection{Evren ve Örneklem}

Araştırmanın evrenini 2017-2018 eğitim-öğretim yılında Antalya'da ortaöğretim kurumlarında öğrenim gören bütün ergenler oluşturmaktadır. Örneklem grubu ise Antalya ilinin Korkuteli ilçesinde bulunan Kız Anadolu İmam Hatip Lisesi, Şehit Yasin Naci Ağaroğlu İmam Hatip Lisesi, Hacı Ethem-Şerife Kavukçu Anadolu Lisesi, Mesude-Erol Memioğlu Mesleki ve Teknik Anadolu Lisesi, Fatma-Mehmet Cadil Fen Lisesi, Lokman Hekim Mesleki ve Teknik Anadolu Lisesi olmak üzere altı farklı lise türünde öğrenim gören ergenlerden tesadüfi olarak seçilen deneklerden oluşmaktadır. Elde edilen verilere kayıp veri analizi uygulanmış ve sonuç itibariyle 605 deneğin verdiği yanıtlar değerlendirmeye alınmıştır. Örneklemin \%58,7’ sini ( $(s=355)$ kız öğrenciler, \%41,3’ ünü ( $s=250$ ) erkek öğrenciler oluşturmaktır. 5000 kişilik bir evren için $\% 99$ güven düzeyi $\pm 5 \%$ göz yumulabilir yanılgı standardı kapsamında örneklem sayısının 586 olarak kabul edilmektedir (Sencer'den akt. Bahadır, 1999: XI). Bu kabul göz önünde bulundurulduğunda 118.218 kişilik araştırma evreni için değerlendirmeye aldığımız 606 kişilik anket uygulaması, örneklemin kabul edilen sayının üstünde olduğu anlamını taşımaktadır. Dolayısıyla örneklemin evreni temsil gücünün yüksek olduğu düşünülmektedir.

\subsection{Bulgular}

\subsubsection{Araștırma Değișkenleri ve İlgili Alt Boyutlara Ait Betimsel İstatistikler}

Tablo 1 Araştırma Değişkenleri ve İlgili Alt Boyutlara Ait Betimsel İstatistikler

\begin{tabular}{llllll}
\hline & Mean & $\mathrm{N}$ & Std. Deviation & Skewness & Kurtosis \\
\hline Öz-yeterlik & 2,235 & 606 &, 6752 &, 576 &, 226 \\
Diş Özgüven & 2,280 & 606 &, 8153 &, 585 &, 301 \\
İç Özgüven & 2,455 & 606 &, 7792 &, 240 &,- 248 \\
Girişimcilik & 1,665 & 606 &, 5827 &, 832 &, 242 \\
Hak İddia Etme & 2,364 & 606 &, 8963 &, 647 &,- 072 \\
Üstünlük & 3,233 & 606 &, 9860 &,- 324 &,- 679 \\
Kendine Hayranlık & 2,422 & 606 &, 9199 &, 503 &,- 497 \\
Otorite & 2,330 & 606 &, 9397 &, 439 &,- 306 \\
Dini Tutum Toplam & 1,507 & 606 &, 32404 &, 478 & 1,616 \\
Narsizm Toplam & 2,5873 & 606 &, 74416 &, 175 &,- 506 \\
Özgüven Toplam & 2,1604 & 606 &, 51065 &, 124 &, 011 \\
\hline
\end{tabular}

Tabachnick ve Fidell (2013), çarpıklık ve basıklık katsayılarının -1,5 ile +1,5 arasında olduğu durumlarda dağ 1 lımların normal kabul edilebileceğini belirtmektedir. Tablo 2'deki veriler doğrultusunda, ölçekler ve ilgili alt boyutlarının normal dağılım kriterini karşılamadığı ve bu yüzden parametrik olmayan analiz yöntemlerinin kullanılması gerekliliği sonucuna varılmıştır. 


\subsection{2. Ölçekler ve Alt Boyutlar Arasındaki Korelayon Analizleri}

Tablo 2 Dini Tutum ve Davranış, Narsizm ve Özgüven Alt Boyutları Arasındaki Spearman Korelasyon Analizi

\begin{tabular}{|l|l|l|l|l|l|l|l|l|l|l|l|}
\hline & & 2 & 3 & 4 & 5 & 6 & 7 & 8 & 9 & 10 & 11 \\
\hline 1 Dini Tutum & 1,000 & & & & & & & & & & \\
\hline 2 Öz-yeterlik &,$- 366^{* *}$ & 1,000 & & & & & & & & & \\
\hline 3 Diş Özgüven &,$- 166^{* *}$ &, $451^{* *}$ & 1,000 & & & & & & & & \\
\hline 4 İç Özgüven &,$- 107^{* *}$ &, $299^{* *}$ & $402^{* *}$ &, 000 & & & & & & & \\
\hline 5 Girişimcilik &,$- 104^{*}$ &, $262^{* *}$ & $371^{* *}$ & $329^{* *}$ & 1,000 & & & & & & \\
\hline 6 Hak İddia Etme &,$- 242^{* *}$ &, $499^{* *}$ & $449^{* *}$ & $265^{* *}$ &, $233^{* *}$ &, 000 & & & & & \\
\hline 7 Üstünlük &,$- 119^{* *}$ &, $290^{* *}$ &, $293^{* *}$ & $294^{* *}$ &, $185^{* *}$ & $517^{* *}$ &, 000 & & & & \\
\hline 8 KendineHayranlık &,$- 149^{* *}$ &, $343^{* *}$ &, $265^{* *}$ & $188^{* *}$ & $183^{* *}$ & $530^{* *}$ & $597^{* *}$ &, 000 & & & \\
\hline 9 Otorite &,$- 249^{* *}$ &, $510^{* *}$ &, $348^{* *}$ &, $314^{* *}$ &, $220^{* *}$ & $569^{* *}$ & $462^{* *}$ & $414^{* *}$ &, 000 & & \\
\hline 10 NarsizmToplam &,$- 236^{* *}$ &, $507^{* *}$ & $414^{* *}$ & $317^{* *}$ & $241^{* *}$ & $804^{* *}$ & $816^{* *}$ & $794^{* *}$ & $755^{* *}$ &, 000 & \\
\hline 11 ÖzgüvenToplam &,$- 229^{*}$ &, $662^{* *}$ & $790^{* *}$ & $722^{* *}$ & $626^{* *}$ & $489^{* *}$ & $354^{* *}$ & $323^{* *}$ & $470^{* *}$ & $498^{* *}$ & 1,000 \\
\hline
\end{tabular}

Tablo 2' deki korelasyon bulgularına göre,

Dini tutum ve davranışlar ile öz-yeterlik ( $r=-, 366 ; p<0,01)$, dış özgüven ( $r=-, 166 ; p<0,01)$, iç özgüven ( $r=-, 107 ; p<0,01)$, girişimcilik $(r=-, 104 ; p<0,05)$, hak iddia etme $(r=-, 242 ; p<0,01)$, üstünlük ( $\mathrm{r}=-, 119 ; \mathrm{p}<0,01)$, kendine hayranlık $(\mathrm{r}=-, 149 ; \mathrm{p}<0,01)$, otorite $(\mathrm{r}=-, 249 ; \mathrm{p}<0,01)$, narsizm toplam puan $(r=-, 236 ; p<0,01)$ ve özgüven toplam puan $(r=, 229 ; p<0,01)$ negatif yönlü ve anlamlı ilişkilidir.

Öz-yeterlik alt boyutu ile hak iddia etme ( $r=, 499 ; p<0,01)$, üstünlük $(r=, 290 ; p<0,01)$, kendine hayranlık $(\mathrm{r}=, 343 ; \mathrm{p}<0,01)$ ve otorite $(\mathrm{r}=, 510 ; \mathrm{p}<0,01)$ alt boyutlarının pozitif yönlü ve anlamlı ilişkili oldukları tespit edilmiştir.

Diş özgüven alt boyutu ile hak iddia etme ( $r=, 449 ; \mathrm{p}<0,01)$, üstünlük $(r=, 293 ; \mathrm{p}<0,01)$, kendine hayranlık $(\mathrm{r}=, 265 ; \mathrm{p}<0,01)$ ve otorite $(\mathrm{r}=, 348 ; \mathrm{p}<0,01)$ alt boyutlarının pozitif yönlü ve anlamlı ilişkili oldukları saptanmıştır.

İç özgüven alt boyutu ile hak iddia etme $(r=, 265 ; \mathrm{p}<0,01)$, üstünlük $(\mathrm{r}=, 294 ; \mathrm{p}<0,01)$, kendine hayranlık $(\mathrm{r}=, 188 ; \mathrm{p}<0,01)$ ve otorite $(\mathrm{r}=, 314 ; \mathrm{p}<0,01)$ alt boyutlarının pozitif yönlü ve anlamlı ilişkili oldukları gözlenmiştir.

Girişimcilik alt boyutu ile hak iddia etme $(r=, 233 ; p<0,01)$, üstünlük ( $r=, 185 ; p<0,01)$, kendine hayranlık $(\mathrm{r}=, 183 ; \mathrm{p}<0,01)$ ve otorite $(\mathrm{r}=, 220 ; \mathrm{p}<0,01)$ alt boyutlarının pozitif yönlü ve anlamlı ilişkili oldukları tespit edilmiştir. 


\subsection{3. Ölçeklerin İç Tutarlılık Katsayıları}

Tablo 3 Ölçeklerin İç Tutarlılık (Cronbach Alpha) Katsayıları

\begin{tabular}{ccc}
\hline İç Tutarlılık & Cronbach's Alpha & Madde sayısı \\
\hline Dini Tutum &, 780 & 36 \\
\hline Narsizm &, 822 & 18 \\
\hline Özgüven &, 903 & 21 \\
\hline
\end{tabular}

Tablo 3'te araştırmada kullanılan ölçeklerin iç tutarlılık katsayıları incelendiğinde dini tutumlar 0,78 , narsizm 0,82 ve özgüven 0,90 olarak bulunmuştur.

\subsubsection{Narsizm ve Özgüveni Etkileyen Değișkenlerin Regresyon Analizleri}

Tablo 4 Narsizmi Etkileyen Değişkenlerin Doğrusal Regresyon Analizi

\begin{tabular}{|c|c|c|c|c|c|c|c|c|}
\hline \multicolumn{2}{|c|}{ Model } & \multirow{2}{*}{$\begin{array}{l}\mathrm{B}(\mathrm{b}) \\
1,194\end{array}$} & \multirow{2}{*}{$\begin{array}{l}\text { Sh } \\
185\end{array}$} & \multirow{2}{*}{$\begin{array}{l}\text { Beta } \\
(\boldsymbol{\beta}) \\
\end{array}$} & \multirow{2}{*}{$\begin{array}{l}\mathrm{T} \\
6,439\end{array}$} & \multirow{2}{*}{$\begin{array}{l}\mathrm{F} \\
60,525^{* * *}\end{array}$} & \multirow{2}{*}{$\begin{array}{l}\mathrm{P} \\
, 000\end{array}$} & \multirow{2}{*}{$\begin{array}{l}\mathrm{R} 2 \\
0,33 \\
\end{array}$} \\
\hline 1 & Sabit $(\alpha)$ & & & & & & & \\
\hline & DiniTutumtoplam &,- 177 & ,080 &,- 077 & $-2,214$ & &, $027^{*}$ & \\
\hline & Öz-yeterlik & ,421 & ,043 & ,382 & 9,754 & &, $000 * * *$ & \\
\hline & Dış Özgüven & ,148 & ,036 & ,163 & 4,085 & &, $000 * * *$ & \\
\hline & İç Özgüven & ,132 & 035 & ,138 & 3,771 & &, $000^{* * * *}$ & \\
\hline & Girişimcilik & ,034 & ,047 & ,027 & ,734 & & ,463 & \\
\hline
\end{tabular}

Bağımlı değişken: Narsizm $\quad{ }^{* * *} \mathrm{p}<0,001 \quad * * \mathrm{p}<0,01 \quad * \mathrm{p}<0,05$

Dini tutum ve davranışlar ile özgüvenin narsizme etkisini incelemek için yapılan doğrusal regresyon analizine göre oluşturulan model istatistiksel olarak anlamlıdır $[\mathrm{F}(5 / 600)=60,525$; $\mathrm{p}<0,001]$. Bağımsız değişkenler incelendiğinde, dini tutum ve davranışlar $(\beta=-, 07 ; p<0,05)$, öz-yeterlik $(\beta=0,38 ; p<0,01)$, diş özgüven $(\beta=0,16 ; p<0,01)$, iç özgüven $(\beta=0,14 ; p<0,01)$ anlamlı düzeyde narsizmi etkilemektedir. Bulgular doğrultusunda, öz-yeterlik, dış ve iç özgüven boyutlarından alınan yüksek puanlar, öğrencilerin narsizm toplam puanlarını anlamlı düzeyde açıklamaktadır. Ayrıca, dini tutumdan alınan düşük puanlar narsizm puanlarının yüksek oluşunu anlamlı düzeyde açıklamaktadır. Saptanan açıklayıcı ilişki \%33 oranında anlamlıdır (düzeltilmiş(adjusted) $\mathrm{R}^{2}=0,33$ ). 
Tablo 5 Özgüveni Etkileyen Değişkenlerin Doğrusal Regresyon Analizi

\begin{tabular}{|l|l|l|l|l|l|l|l|l|}
\hline \multicolumn{2}{|l|}{ Model } & $(\mathrm{b})$ & Sh & Beta $(\boldsymbol{\beta})$ & $\mathrm{t}$ & $\mathrm{F}$ & $\mathrm{P}$ & $\mathrm{R} 2$ \\
\hline \multirow{3}{*}{1} & Sabit $(\alpha)$ & 1,527 &, 115 & & 13,327 & $59,055^{* * *}$ &, 000 & 0,32 \\
\cline { 2 - 9 } & DiniTutum Toplam &,- 155 &, 054 &,- 098 & $-2,855$ & &, $004^{* *}$ & \\
\cline { 2 - 9 } & Hak İddia Etme &, 175 &, 025 &, 306 & 6,852 & &, $000^{* * *}$ & \\
\cline { 2 - 9 } & Kendine Hayranlik &,- 010 &, 024 &,- 018 &,- 406 & &, 685 & \\
\cline { 2 - 7 } & Üstünlük &, 137 &, 023 &, 253 & 6,063 & &, $000^{* * *}$ & \\
\cline { 2 - 9 } & Otorite &, 049 &, 023 &, 095 & 2,117 & &, $035^{*}$ & \\
\hline
\end{tabular}

Bağımlı Değişken: Özgüven $\quad{ }^{* * *} \mathrm{p}<0,001^{* *} \mathrm{p}<0,01$ *p $<0,05$

Dini tutum ve davranışlarla narsizm alt boyutlarının özgüvene etkisini incelemek için yapılan doğrusal regresyon analizine göre oluşturulan model istatistiksel olarak anlamlıdır $[\mathrm{F}(5 / 600)=59,055 ; \mathrm{p}<0,001]$. Bağımsız değişkenler incelendiğinde, dini tutum ve davranışlar $(\beta=-09 ; p<0,001)$, hak iddia etme $(\beta=0,30 ; p<0,01)$, kendine hayranlık $(\beta=-0,18 ; p<0,05)$, üstünlük $(\beta=0,25 ; \mathrm{p}<0,01)$ ve otorite $(\beta=0,09 ; \mathrm{p}<0,01)$ narsizmi anlamlı düzeyde etkilemektedir. Bulgular doğrultusunda, dini tutumlar ve kendine hayranlık alt boyutları özgüveni negatif yönlü ve anlamlı düzeyde açıklamaktadır. Ayrıca, hak iddia etme, üstünlük üstünlük ve otorite alt boyutlarından alınan yüksek puanlar, öğrencilerin özgüven toplam puanlarını anlamlı düzeyde açıklamaktadır. Saptanan açıklayıcı ilişki \%32 oranında anlamlıdır (düzeltilmiş(adjusted) $\mathrm{R}^{2}=0,32$ ).

\section{Değerlendirme}

Araştırma sorularının yanıtlandığı çalışmada, ilk olarak, öğrencilerin dindarlık düzeyleri ile narsizm eğilimleri ve özgüven durumları arasındaki ilişki ele alınmıştır. Bulgulara göre, dindarlık düzeyi ile narsizm eğilimi ve özgüven durumu arasında negatif yönlü anlamlı bir ilişki olduğu bulunmuştur. Buna göre dindarlık düzeyi artıkça Narsizm ve özgüven azalmaktadır. Araştırmada elde edilen bulgunun literatürle tutarlı olduğu görülmektedir (Kartopu, 2013: 630). Örneğin, Kartopu (2013: 625) tarafindan yapılan çalışmada, Gümüşhane Üniversitesinde, farklı fakültelerde öğrenim gören üniversite öğrencileriyle yapmış olduğu çalışmada, dindarlık düzeyleri yüksek olan öğrencilerde narsizm düzeylerinin en düşük olduğu sonucu elde edilmiştir.

Yapılan araştırmaların bir kısmında, özellikle benlik saygısı ve narsizm ile ilişkilendirilen diğer bir değişken olan problemli internet kullanımı ve dindarlık arasındaki ilişki incelenmiştir (Nadeem vd., 2018: 6). Çalışmada, din karşıtı olan öğrencilerde problemli internet kullanımına karşılık gelen yüksek skorlar saptanmıştır. Sonuçlar, öğrencilerin internet bağımlılığı geliştirmesi hususunda dindarlığın önleyici işlevi olduğunu göstermektedir.

Cooper ve Pullig (2012: 167), narsizmin bireylerin etik yargılarını yüksek oranda olumsuz etkilediğini ifade etmişlerdir. Yazarlar, bireylerin dini yatkınlıklarının fazla olmasına karşın dini açıdan uygun olmayan bazı davranışlara yöneliminin narsizmle açıklanabilecek bir durum 
olduğunu ifade etmişlerdir. Cooper ve meslektaşları (2016: 42), kapsamını genişlettikleri bir diğer çalışmada, özellikle toplumsal düzeyde dini tutum ve davranışlara önem veren bireylerde kendine güven ve etik anlayışının daha fazla; narsizmin ise daha düşük olduğu sonucu elde edilmiştir. Orhan (2014: 141) tarafından yapılan araştırmada ise ailesinin dindarlık eğilimi düşük olan çocukların narsistik eğilimlerinin daha fazla olduğu sonucu elde edilmiştir. Elde edilen bulgunun bu çalışmada saptanan narsizm eğilimi, özgüven durumu ve dindarlık arasındaki negatif yönlü anlamlı ilişki ile tutarlılık gösterdiği görülmektedir.

Ashawy (2016: 84) tarafından 9. Sınıf öğrencilerinin dindarlık düzeyleri ve narsizm özellikleri arasındaki ilişkinin incelendiği araştırmanın bulgularına göre, öğrencilerin dindarlık düzeyleri ve narsizm eğilimleri arasında negatif yönlü ve anlamlı ilişki saptanmıştır.

Buzdar ve meslektaşları (2018: 1) tarafından, Pakistanlı üniversite öğrencileriyle yapılan çalışmada, dindarlığın narsistik kişilik bozukluğu belirtilerini azaltıp azaltmadığı incelendiği çalışmaya 618 kişi katılmıştır. Araştırmada elde edilen bulgular doğrultusunda, narsistik kişilik bozukluğu belirtilerinin öğrencilerin iç güdümlü veya dış güdümlü dindarlık yönelimleri üzerinde doğrudan etkisi olduğu bulgulanmıştır. Araştırmada elde edilen bulgular doğrultusunda, değişime açık dindar bireylerde narsistik kişilik bozukluğu belirtilerinin azaldığı tespit edilmiştir. Güven (2019: 236) tarafından yapılan çalışmada, dindarlık ve içsel dini motivasyonun narsizm ile negatif yönlü ve alçakgönüllülük ile pozitif yönlü anlamlı ilişkisi olduğu sonucu elde edilmiştir.

Daghigh ve meslektaşları (2019: 96) tarafından 388 üniversite öğrencisiyle yapılan çalışmada, dindarlık ve patolojik narsizm incelenmiştir. Araştırmada elde edilen bulgulara göre kırılgan narsizmin dindarlık düzeyini anlamlı düzeyde etkilemediği sonucu elde edilmiştir. Ancak büyüklenmeci narsizmin dindarlık eğilimine pozitif yönde etki ettiği sonucu elde edilmiştir. Öte yandan Ulusal (2019: 107) tarafindan yapılan çalışmada öğrencilerin dindarlık düzeyleri ve narsizm arasında anlamlı ilişki saptanmamakla birlikte öğrencilerin sosyal medya kullanımı ve narsizm düzeyleri arasında anlamlı ilişki olduğu sonucu elde edilmiştir. Sonucun, bu çalışmadaki bulgulardan farklı olduğu görülmektedir.

Narsizm ve özgüven arasındaki negatif yönlü anlamlı ilişkiye yönelik gerçekleştirilen benzer bir çalışmada, Hyatt ve meslektaşları (2018: 1), narsizm ve özgüven arasında pozitif yönlü anlamlı ilişki olduğunu ve benzer kişilik profillerinin narsizm ve özgüven belirtileriyle örtüştüğünü ifade etmişlerdir.

Gürsu ve Apaydın (2016: 551) tarafından gerçekleştirilen araştırmada, narsizm ve özgüven arasındaki ilişkide İslami eğilimin aracı rolü incelenmiştir. Akdeniz Üniversitesi’nde görev yapan 171 öğretim üyesiyle yapılan çalışmada, narsizm ve İslami eğilim arasında anlamlı korelasyon olmadığı sonucu elde edilmiştir. Bununla birlikte, narsizm ve özgüven arasında pozitif yönlü anlamlı bir ilişki saptanan çalışmada, özgüven ile İslami eğilim arasında negatif yönlü anlamlı bir ilişki bulunmuştur. Elde edilen sonucun, narsizm ve İslami eğilim arasındaki ilişkinin anlamlı olmaması sebebiyle bu çalışmadan farklı olduğu, narsizm ve özgüven arasındaki ilişki ile özgüven ve İslami eğilim arasındaki ilişki bakımından benzer olduğu görülmektedir. Başka bir deyişle narsizm ile İslâmî eğilim arasında ilişki bulunmamakla birlikte, narsizm 
ile özgüven arasında pozitif yönde, İslâmî eğilim ile özgüven arasında negatif yönde anlamlı ilişki tespit edilmiştir. Sonuç olarak öğretim üyelerinde narsistlik arttıkça özgüvenlerinin yükseldiği, İslâmî eğilimlerinin ise azaldığı bulgulanmıştır. Bu farklılığın sebebinin çalışmanın birinde örneklemi belli bir akademik kariyere sahip öğretim üyeleri oluştururken diğerinde ortaöğretim öğrencisi ergenlerin oluşturması olduğu düşünülmektedir.

Baumeister ve meslektaşları (1996: 10; 1998: 645), araştırmalarında yüksek narsizm ve saldırganlık ile yüksek özgüven arasında pozitif yönlü anlamlı bir ilişki olduğunu saptamışlardır. Araştırmada elde edilen bulgular sonucunda narsizm ve özgüven arasında pozitif yönlü ilişkiyi gösteren tutarlı sonuçların elde edildiği düşünülmektedir.

Araştırmamızda yer alan dini tutum ve davranış ölçme envanterinden alınan puanlar ile narsizm ve özgüven alt boyutlarından alınan puanlar arasındaki ilişki incelendiğinde, dini tutum ve davranış ölçme envanteri puanı ile hak iddia etme, üstünlük, kendine hayranlık, otorite, öz-yeterlik, dış özgüven, iç özgüven, girişimcilik puanları, narsizm ve özgüven toplam puanları arasında negatif yönlü anlamlı bir ilişki tespit edilmiştir. Bir anlamda dindarlık artıkça narsizm ve özgüven alt boyutlarının birçoğu büyük oranda azalmaktadır. Ergenlerin dindarlık düzeyleri ile narsizm eğilimleri arasındaki negatif yönlü ilişkinin, narsizm ve maddi değerler arasındaki ilişki ile açıklanabileceği düşünülmektedir. Dindarlığın manevi değerler olarak değerlendirilmesine ek olarak, bireylerin narsizm düzeylerinin daha çok maddi değerlerle ilişkili olabileceği düşünülmektedir. Bu görüşün desteklendiği bir çalışmada Çebi (2016: 32), ergenlerde narsizm ve maddi değerler arasında pozitif yönlü ve anlamlı ilişki olduğunu saptamıştır. Kardaş ise (2017: 105), üniversite öğrencilerinde narsizm ve spiritüel iyi oluş arasında negatif yönlü ilişki olduğunu tespit etmiştir.

Dini tutum ve davranış ölçme envanteri puanları ve özgüven alt boyutlarından öz-yeterlik, dış özgüven ve iç özgüven puanları narsizmi anlamlı düzeyde etkilemektedir. Bulgular doğrultusunda, öz-yeterlik, dış ve iç özgüven boyutlarından alınan yüksek puanlar, öğrencilerin narsizm toplam puanlarını anlamlı düzeyde açıklamaktadır. Ayrıca, dini tutum ve davranış ölçeğinden alınan düşük puanlar narsizm puanlarının yüksek oluşunu anlamlı düzeyde açıklamaktadır. Dindarlık düzeyinin, yetkinlik algısı veya özgüven gibi kavramlardan farklı olarak alçakgönüllülük ile bağdaştırıldığını ve bireylerin manevi değerlere daha fazla önem vermesi sebebiyle kendilerini değerlendirme konusunda mütevazı bir tutum sergileme eğiliminde olduğunu öne süren Güven'in (2016: 283) bulguları elde edilen araştırma sonucu ile örtüşmektedir.

Dini tutum ve davranış ölçme envanteri puanları ve narsizm alt boyutlarının (hak iddia etme, kendine hayranlık, üstünlük ve otorite) puanları özgüveni anlamlı düzeyde etkilemektedir. Bulgular doğrultusunda, dini tutum ve davranış ölçe envanteri puanı ve kendine hayranlık alt boyut puanı özgüveni negatif yönlü ve anlamlı düzeyde açıklamaktadır. Ayrıca, hak iddia etme, üstünlük ve otorite alt boyutlarından alınan yüksek puanlar, öğrencilerin özgüven toplam puanlarını anlamlı düzeyde açıklamaktadır. Bu durumun, narsizm düzeylerinin bireylerin kendilerine verdiği değerin ve hissettikleri özgüvenin fazla oluşuyla bağlantılı olduğu şeklinde yorumlanabilir. Ethem'in (2019: 48) belirttiği üzere, narsizm boyutu olan üstünlük kurmaya 
ilişkin tutum ve davranışların, bireylerin kendilerine duydukları güven ve kendilerini aşırı değerli görmeyle ilişkisi bulunmaktadır.

Özgüven alt boyutlarından (öz-yeterlik, dış özgüven, iç özgüven ve girişimcilik) ile narsizm alt boyutlarından (hak iddia etme, üstünlük, kendine hayranlık ve otorite) alınan puanlar arasında pozitif yönlü anlamlı bir ilişki saptanmıştır. Narsizmin kavramsal çerçevesi ele alındığında, narsist bireylerin kendilerine verdiği değer ve özgüveni aşırı düzeydedir. Ayrıca, narsist bireylerin diğer insanlardan alacağı olumlu veya olumsuz tepkiler, özgüven ve kendilerine verdiği değeri olumsuz açıdan etkilememektedir. Narsizm eğilimi ve özgüven durumları arasında bu araştırmada saptanan pozitif yönlü anlamlı ilişki yapılan diğer çalışmalarla tutarlı olduğu görülmektedir.

\section{Sonuç}

$\mathrm{Bu}$ araştırmada temel olarak ergen bireylerde dindarlık, narsizm ve özgüven değişkenleri arasındaki ilişki ele alınmıştır. Ergenlik dönemi, gelişim dönemleri içerisinde oldukça önemli bir yere sahiptir. Kimlik arayışı, karmaşasının haricinde dini tutum ve davranışlarda belirgin değişimlerin olduğu, aynı şekilde dini şüphe ve tereddütlerin yoğun olduğu ergenlik dönemi içerisinde narsizm ve özgüven kavramları da önem taşımaktadır.

Ergenlerin dindarlık düzeyleri ile narsizm eğilimleri ve özgüven durumları arasındaki ilişki incelendiğinde, dindarlık düzeyi ile narsizm eğilimi ve özgüven durumu arasında negatif yönlü anlamlı bir ilişki olduğu saptanmıştır.

Ergenlerin dini tutum ve davranı̧̧ ölçme envanterinden aldıkları puan ile narsizm alt boyutları (hak iddia etme, üstünlük, kendine hayranlık, otorite), özgüven alt boyutları (öz-yeterlik, dış özgüven, iç özgüven, girişimcilik) puanları, narsizm ve özgüven toplam puanları arasında negatif yönlü anlamlı bir ilişki tespit edilmiştir. Bu sonuç, dinin değer yargıları, prensip ve dayanaklarının özgüven ve narsizm kavramlarının dayanaklarından farklı olduğunu göstermektedir.

Araştırma bulgularına göre, dini tutum ve davranış ölçme envanteri puanları ve özgüven alt boyutlarından öz-yeterlik, dı̧̧ özgüven ve iç özgüven puanları narsizmi anlamlı düzeyde etkilemektedir. Sonuç, literatürle paralellik arz etmektedir. Sadece özgüven alt boyutlarından girişimcilik puanı narsizmi etkilememiştir.

Dini tutum ve davranış ölçme envanteri puanları ve narsizm alt boyutlarından alınan puanlar özgüveni anlamlı düzeyde etkilemektedir. Araştırmada elde bulgunun alanyazınla tutarlı olduğu görülmektedir. Diğer narsizm alt boyutlarının tersine kendine hayranlık alt boyutu puanı özgüveni negatif yönlü ve anlamlı düzeyde etkilemektedir.

Araştırmada Özgüven alt boyutları (öz-yeterlik, dış özgüven, iç özgüven ve girişimcilik) puanları ile narsizm alt boyutları (hak iddia etme, üstünlük, kendine hayranlık ve otorite) puanları arasında pozitif yönlü anlamlı bir ilişki saptanmıştır. İlgili literatürde yer alan çalışmalarla tutarlılık gösteren sonucun, kendilerine çok fazla değer veren ve aşırı güvenen, diğer insanların görüş, düşünce ve ihtiyaçlarını hiç önemsemeyen narsistik kişilik özelliklerine bağlı olduğu düşünülmektedir. 
Kendini çok sevme, kibirlilik, büyüklenme gibi anlamlara gelen ve bir kişilik bozukluğu olan narsizm günümüzde bir salgın haline dönüşmüştür. Teknoloji vasıtasıyla hızla yayılma imkanı bulan narsizm hiç kuşkusuz teknoloji ve internet nesli olan gençlerimizi kuşatmış ve en fazla etkisini onlar üzerinde göstermektedir.

Sağlıklı bir kişilik özelliği olarak değerlendirilen yüksek özsaygı ve özgüven kavramları ile psikolojik sağlik arasında olumlu bir ilişkinin olduğunu gösteren bulgular olmakla birlikte bu araştırmada olduğu gibi yeni araştırmalar, yüksek özsaygı ve özgüven ile narsizm kavramlarının genellikle birbirine karıştırıldığını, özsaygıyı ve özgüveni yükseltmek için kullanılan bütün tekniklerin ise gerçekte narsizmi artırdığını göstermektedir.

Araştırma sonuçlarına dayanarak narsizmin abartılı bir özgüven durumu olduğu ifade edilebilir. Ayrıca narsist bireylerde kendilerini üstün olarak görme, yüksek özgüvenli bireylerde ise kendilerini değerli görme güdüsünün baskın olduğu şeklinde bir çıkarsama yapılabilir. Ancak her ikisinin de dayanağı başkalarının kendilerini nasıl algıladığı düşüncesine dayanmaktadır.

Sonuç olarak inanç, tutum-davranış ve diğer tüm kişilik özellikleri bireyin kimliğinin oluşmas1 noktasında bir bütündür ve hepsi birbirini etkilemektedir. Narsistik Kişilik Envanterinde yüksek puan alanların özgüven ve özsaygı puanları da yüksek çıkmaktadır. yüksek özgüven ve özsaygının sınırlarının belirsiz olması nedeniyle faydalı olabileceği gibi narsistik kişilik bozukluğuna yol açabileceği de görülmektedir. Ergenlerin dindarlık seviyeleri ile narsizm ve özgüven arasındaki negatif yönlü anlamlı ilişki de dikkate alınırsa narsizm ve yüksek özgüven gibi patolojik rahatsızlıkların terapi sürecinde, son dönemde çokça vurgulanan ve üzerine çeşitli çalışmalar yapılan dinin iyileştirme etkisinin göz ardı edilmemesi gerektiği ve doğrudan sürece dahil edilmesinin gerekli olduğu düşünülmektedir.

Zamanımızda kadim geleneklerle dinlerin uygun görmediği ve sıklıkla yerdiği; yüksek özgüvene yol açan kendini övmek, beğenmek, kibir, haddini bilememek gibi kavramların sosyal medya, popüler kültür ve bazen de ilim çevreleri tarafindan sahip olunması gereken vasıflarmış gibi değerlendirilmesi olumsuz sonuçlara neden olabilmektedir. Hatta ebeveyn ve eğitimciler iyi niyetle çocuk ve ergenlerde özgüveni geliştirmeye çalı̧̧ırken aslında farkında olmadan onları narsistik kişilik bozukluğuna da sürükleyebilmektedirler. Bu nedenle terapi sürecinde kadim mesajların dikkate alınarak narsizm kadar yüksek özsayg1 ve özgüvenin de aslında olumsuzluklar içerebildiği, bazen mevcut rahatsızlı̆̆ın temelinde bu olguların olabileceği düşüncesine yer vermek yerinde olacaktır. Bununla birlikte tartışmaya açık olan bu konularda daha kesin konuşabilmek için çok daha fazla ve ileri çalışmaya ihtiyaç duyulduğunu da belirtmek yerinde olacaktır.

\section{KAYNAKÇA}

Akın, A. (2007). Öz-güven ölçeğinin geliştirilmesi ve psikometrik özellikleri. Abant İzzet Baysal Üniversitesi eğitim Fakültesi Dergisi, 7(2), 167- 176.

Ashawy, M.F.A.A.A. (2016). Ortä̈̆gretim Öğrencilerinde Dindarlık ve Narsizm İlişkisi (Sinop Örneği). Yayımlanmamı̧ Yüksek Lisans Tezi, Ondokuz Mayıs Üniversitesi Sosyal Bilimler Enstitüsü, Samsun. 
Baumeister, R. F. (1998). “The self. In D. T. Gilbert, S. T. Fiske, G. Lindzey (Eds.)”. Handbook of Social Psychology, 4(2): 680-740.

Baumeister, R. F. (2001). "Violent Pride: Do People Turn Violent Because of Self-Hate, or Self-Love? Scientific American, 284(4): 96-101.

Baumeister, R. F., Smart, L., Boden, J. M. (1996). "Relation of Threatened Egotism to Violence and Aggression: The Dark Side of High Self-Esteem”. Psychological Review, (103): 5-33.

Behary, W.T. (2018). Narsistle Ateşkes. (Çev. M. Caner ve N. Azizlerli), Psikonet Yayınları, İstanbul.

Budak, S. (2009). Psikoloji Sözlüğ̈̈. Bilim ve Sanat Yayınları, Ankara.

Buzdar, M. A., Tariq, R. U. haq, Jalal, H., Nadeem, M. (2018). “Does Religiosity Reduce Narcissistic Personality Disorder? Examining the Case of Muslim University Students". Journal of Religion and Health, 1-8 doi:10.1007/s10943-018-0628-9.

Cihangir Çankaya, Z. ve Meydan, B. (2018). “Ergenlik Döneminde Mutluluk ve Umut”. Elektronik Sosyal Bilimler Dergisi, 17(65): 207-222.

Cooper, M. J., Pullig, C., \& Dickens, C. (2016). "Effects of Narcissism and Religiosity on Church Ministers with Respect to Ethical Judgment, Confidence, and Forgiveness”. Journal of Psychology and Theology, 44(1): 42-54. doi:10.1177/009164711604400104

Çebi, E. (2016). Ortaokul Öğrencilerinde Maddi Değerler ve Narsisizm. Yayımlanmamı̧̧ Yüksek Lisans Tezi, Gelişim Üniversitesi Sosyal Bilimler Enstitüsü, İstanbul.

Daghigh, A., DeShong, H. L., Daghigh, V., Niazi, M., ve Titus, C. E. (2019). “Exploring the Relation Between Religiosity and Narcissism in an Iranian Sample". Personality and Individual Differences, (139): 96-101.

Emmons, R.A. (1984). Factor analysis and construct validity of the narcissistic personality inventory. Journal of Personality Assessment, 48(3), 291- 300.

Ethem, S. (2019). Narsisizm, Yalnızlık ve İlişkili Olma Gereksinimi ile Facebook, Twitter ve Instagram Kullanımı Arasındaki İlişki. Yayımlanmamış Yüksek Lisans Tezi, Ufuk Üniversitesi Sosyal Bilimler Enstitüsü, Ankara.

Giddens, A. (2004). Modernliğin Sonuçları. (Çev. E. Kuşdil), Ayrıntı Yayıncılık, İstanbul.

Gül, S. K. ve Güneş, İ. D. (2009). “Ergenlik Dönemi Sorunları ve Şiddet”. Sosyal Bilimler Dergisi, 11(1): 79-101.

Gürsu, O. (2011).Ergenlerde Psikolojik Sağglıkve Dindarlık. Yayımlanmış Doktora Tezi, Selçuk Üniversitesi Sosyal Bilimler Enstitüsü, Konya.

Gürsu, O. Apaydın. Ç. (2016). “Narsizm ile Özgüven Arasındaki İlişkide İslami Eğilimin Aracı Rolü”, Ekev Akademi Dergisi, 20(66): 551-562.

Güven, M. (2019). Narsizm, Alçakgönüllülük ve Dindarlık İlişkisi. Yayımlanmamış Doktora Tezi, Atatürk Üniversitesi Sosyal Bilimler Enstitüsü, Erzurum.

Hyatt, C. S., Sleep, C. E., Lamkin, J., Maples-Keller, J. L., Sedikides, C., Campbell, W. K., ve Miller, J. D. (2018). Narcissism and self-esteem: A nomological network analysis. PLOS ONE, 13(8): 1-31. e0201088. doi:10.1371/journal.pone.0201088

Kardaş, S. (2017). Sanal Kimlik ve Spiritüel İyi Oluşun Üniversite Öğrencilerinin Narsisistik Eğilimlerini Yordayııılı̆̆. Yayımlanmamış Doktora Tezi, Marmara Üniversitesi Eğitim Bilimleri Enstitüsü, İstanbul.

Kartopu, S. (2013). “Narsisizmin Dindarlık Eğilimleriyle İlişkisi: Gümüşhane Üniversitesi Örneği”, The Journal of Academic Social Science Studies,6(6): 625-649.

Lauster, P. (2000). Kendine güven, Ankara: Doruk Yayınları. 
Nadeem, M., Buzdar, M. A., Shakir, M., ve Naseer, S. (2018). "The Association Between Muslim Religiosity and Internet Addiction Among Young Adult College Students", Journal of Religion and Health, 1-8, doi:10.1007/s10943-018-0697-91.

Orhan, G. (2014). Narsizm Etiyolojsi ve Dindarlıkla İlişkisi. Yayımlanmamı̧̧ Yüksek Lisans Tezi, Erciyes Üniversitesi Sosyal Bilimler Enstitüsü, Kayseri.

Raskin, R. ve Terry, H. (1988). "A Principal-Component Analysis of the Narcissistic Personality Inventory and Further Evidence of its Construct Validity". Journal of Personality and Social Psychology, 54(5): 890-902.

Raskin, R., \& Hall, C. S. (1979). A narcissistic personality inventory. Psychological Reports, 40, 590.

Schunk, D. H. (2000). Learning Theories, Prentice hall, Third edition. The Gale encyclopedia of psychology / Bonnie R. Strickland, executive editor, Gale Group.

Şahin, Ş. ve Özçelik, Ç.Ç. (2016). "Ergenlik Dönemi ve Sosyalleşme”. Cumburiyet Hemşirelik Dergisi, 5(1): 42-49.

Tabachnick, B., \& Fidell, L. (2013). Using Multivariate Statistics, 6th International edition (cover) edn. Boston, [Mass.].

Twenge, J.M. ve Campbell, W.K. (2015). Asrın Vebası: Narsisizm İlleti. (Çev. Ö. Korkmaz), İstanbul: Kaknüs Yayınları.

Twenge, Jean M.ve Campbell, W.Keith, (2010). Narsisizm İlleti, (çev. Özlem Korkmaz), İstanbul: Kaknüs Yayınları.

Ulusal, R. (2019). Ergenlik Döneminde Narsizm, Dindarlık ve Sosyal Medya Tutumlar İlişkisi. Yayımlanmamı̧̧ Yüksek Lisans Tezi, Marmara Üniversitesi Sosyal Bilimler Enstitüsü, İstanbul. 